\title{
Contemporary Parenting: The Construction of Autonomy in the Parent-Child Relationship
}

\author{
Terezinha Féres-Carneiro*, Celia Regina Henriques, Andrea Seixas Magalhães, \\ Rebeca Nonato Machado \\ Pontifical Catholic University of Rio de Janeiro, Rio de Janeiro, Brazil \\ Email: "teferca@puc-rio.br
}

Received 17 June 2016; accepted 6 August 2016; published 9 August 2016

Copyright (C) 2016 by authors and Scientific Research Publishing Inc.

This work is licensed under the Creative Commons Attribution International License (CC BY).

http://creativecommons.org/licenses/by/4.0/

(c) (i) Open Access

\section{Abstract}

This study aims to discuss the process of construction of autonomy in parent-child practices, trying to understand the roles played by parents and their children in this process. We conducted a qualitative research study based on 132 interviews with parents, children ( 7 - 12 years), and adolescents (13 - 18 years), who were members of middle class families of different configurations living in the city of Rio de Janeiro. During the analysis of construction of autonomy, the following categories emerged from the narratives of respondents: Parenting exercise and gender; flexibility; emotional democracy; transgressions and ruptures; and anxiety of parents towards their children's autonomy process. We found that individuals participate in an interplay and act reciprocally, influencing one another at different levels. We concluded that the construction of autonomy is an interindividual process involving all family members. This process includes a corpus of experiences of everyday parenting practices.

\section{Keywords}

Parenting, Autonomy, Family, Parent-Child Relationship

\section{Introduction}

This study aims to discuss parenting practices involved in the process of acquisition of autonomy within the family. Houzel (2007) investigated the concept of parenting considering three dimensions: Exercise, experience,

\footnotetext{
${ }^{*}$ Corresponding author.
}

How to cite this paper: Féres-Carneiro, T., Henriques, C. R., Magalhães, A. S., \& Machado, R. N. (2016). Contemporary Parenting: The Construction of Autonomy in the Parent-Child Relationship. Psychology, 7, 1185-1194. 
and practice. The first dimension, parenting exercise, is related to the exercise of duties relating to kinship and affiliation. The second dimension, parenting experience, includes the conscious and unconscious subjective experiences concerning parental roles. The third dimension, parenting practice, comprises the performance of everyday tasks of parenting with their children, in addition to physical and mental health care of the offspring. These three dimensions serve as limits for a better understanding of the functions and roles of each family member. In the present study, we focused on parenting practice although the other two dimensions are also considered.

Parenting practice is related to the everyday activities performed by parents and children in their daily relationship. This practice includes physical and psychological care related to the child's affection and parental figures (Magalhães \& Féres-Carneiro, 2011), as well as parents’ psychic processes, constituting an interactive dimension (Henriques, Féres-Carneiro, \& Ramos, 2011). Different authors emphasize that autonomy, which is an essential dimension of human relations, develops in the democratic environment of personal life (Gallagher, Féres-Carneiro, \& Henriques, 2013; Giddens, 1992; Reichert \& Wagner, 2007; Wagner \& Grzybowski, 2003; Zanetti \& Gomes, 2011). In this context of exchange and partnership, it is important to understand the role of each member of the family-father, mother, children, and adolescent children-in the construction of autonomy, considering it an ongoing process.

\section{Autonomy in the Family}

The word autonomy comes from Greek and it is comprised of the adjective autos, meaning by itself, and the noun nomus, which means sharing, convention, law. Autonomy is usually thought to be a process linked to young individuals, children, or adolescents. However, according to Winnicott (1965), both youths or adults are never complete, they are always developing in an ongoing process and a permanent interaction with the environment. Therefore, autonomy is seen as a journey based on interrelationships involving individuals of all ages.

According to Winnicott (1965), the family establishes a course of transition from parental (or maternal) care to the individual's social life in his path towards relative maturity. In terms of young children, there is the concept of a relational space that fails, that is, parents (or mother) who frustrate the child so that the child is able to grow. Ramos (2006) and Henriques, Féres-Carneiro and Ramos (2011) pointed out that young adult children cause instabilities in the relational environment in order to move beyond the limits imposed by parents while relying on their veiled consent.

Considering autonomy within the family, each family member is a unique interlocutor; therefore, the scope of action of the family group gives way to interindividual negotiations (Ramos, 2006), constituting the corpus of autonomy. A step taken by one family member guides the step of another member. Thus, there is a dynamic environment where very small changes are followed by actions that enable the development of a sense of autonomy and self-definition. This practice refers to the father-child dyad and mother-child dyad, all of them mutually involved.

Although autonomy is a unique process, it is linked to the social and cultural context. In industrialized societies (Bauman, 2003), characterized by individualism (Singly, 2007), and in middle class families, children's autonomy is based on the relationship with parents (Ponciano \& Féres-Carneiro, 2014). The connection between parental figures and children promotes autonomy in a context of availability and presence of parents.

According to Barbosa and Wagner (2013) and Ponciano and Féres-Carneiro (2014), parental separation occurs at the same time as children's acquisition of autonomy. These authors believe that the parents' action in this process may be strategic. Thus, parents' separation movement may be seen as a displacement that serves both as a facilitator for children's autonomy acquisition and as a process of differentiation between parents and their children, promoting parents' independence. Hence, autonomy is an interindividual process embodied by all participants in the current parenting practice.

Sant'Ana (2009) stated that, in modern times, the association of rationality and individuality promotes the individual's active role in the world. Such active role encompasses the idea of fighting against heteronomy, that is, passive acceptance of traditional norms and values. Giddens (1991) contributed to this debate with the concept of reflexivity, which he considers to be a characteristic of modernity. Because reflexivity continuously generates self-knowledge, it includes reflection on the nature of reflection itself. Sant'Ana (2009) stressed that the reflective capacity makes it possible for an individual to put himself in someone else's place and feel the experience in the same way as the other person does, even if avoiding to adopt the other person's perspective as his own. 
In this sense, reflective capacity leads to self-determination and autonomy. Furthermore, according to Sant' Ana (2009), this encounter between two individuals results in a shared response, even if minimal. In the words of Giddens (1992), the principle of autonomy in the field of personal life means relating to others in an equal way. Autonomy could not develop in a context without democracy of personal life.

These notions are relevant to think about autonomy within family relationships. In a democracy of personal life, the principle of equality is an assumption in the relationships, including the parents-children relationship. Giddens (1992) pointed out that autonomy and authority are strictly necessary in a discussion aimed at understanding the dynamics of families. Thus, self-development should be free and equal, and there should also be limited power. Power should be distributed in a democratic manner, considering the public sphere. However, this limitation of power does not mean a denial of authority. According to Giddens, such limit is only justified to the extent that it recognizes the principle of autonomy.

Based on Giddens's concept of pure relationship, authority exists as an aspect of expertise. In other words, a person develops specific skills that the other one lacks; this is not exactly authority over the other, but to be wiser than the other. In a relationship between parents and children, in which authority is present, whether explicitly or not so, it is assumed that the individuals are able to express ideas on the same level of equality. "To speak of fostering an emotional democracy doesn't mean being weak about family duties” (Giddens, 2007: p. 73).

Caillé (2003) discussed the method of questioning authority, especially in the family context, triggered by the 1968 movement, which was a symbol of social changes. Relationships started to be regulated by affection and by the consensus required by affection. Children born after the 1970s were and are being raised based on mutual respect, with greater symmetry in their relationship with their parents, and with hedonism as a key value. However, the speech of contemporary families is often confronted with relatively classic social behaviors originated from the external world (outside the family context).

Studies conducted with families have found that parents are facing some difficulties arising from the fact that they confuse authority with authoritarianism (Féres-Carneiro, Ziviani, Magalhães, \& Ponciano, 2013; FéresCarneiro \& Magalhães, 2014). For fear of being authoritarian, parents fail to exercise authority and act as if the family were a group of equals. Similarly to a democratic society, the democratic family needs a hierarchy so that children can develop in a healthy manner.

\section{Reciprocity and Contemporary Parenting Practices}

Considering the exercise of parenting in married, separated, remarried, single and, more recently, homosexual-parent families, there is an increasing number of parents that are confused and ambivalent regarding their parental duties. Salem (2007) stated that the fading of the boundaries between male and female is a contribution of the principle of equality, which guides the relationship between genders. This guideline serve as the basis for the creation of an ideal of marital system called egalitarian couple, which fosters discussions on the exercise of maternal and paternal roles. Jablonski (2010) added to this debate by stating that men play a supporting role in the division of household chores. Furthermore, the author stressed that such division is often more focused on traditional principles than assumed by those involved. This finding puts into play the ideal of gender equality and its discontinuation observed in the private life of families.

Eiguer (2008) pointed out that the psyches of two or more individuals function based on a principle of reciprocity, influencing one another at several levels. The notions about the process of being a parent and a son/daughter are examples of psychic changes that depend on mutuality. Therefore, such changes also depend on a reciprocal experience of "being" between parents and their children. Conversely, there is a paradox in the process of belonging to a family group because, at the same time as it is necessary to preserve each individual's uniqueness, there is need to establish a common history, which is the substance of the "family self" (Eiguer, 1985) thus promoting the feeling of belonging.

According to Caillé (2003), contemporary parents live a transitional crisis built by two models of contradictory and irreconcilable societies. The author describes these models in terms of mythologies and explains them within the context of families, classifying the families into neotraditional and affection-focused families. In neotraditional families, parental roles are similar, but they have some distinctions and conditions according to the parents' gender. This mythology determines that adults transfer values and traditions to their children, preserving a family identity across generations. In this sense, individuals build themselves as unique human beings, playing or rejecting the roles related to their age or gender assigned to them by the family narrative. 
The affection-focused family, on the other hand, is built around the child, which is a project of one or more adults. Therefore, the child carries the implicit responsibility to provide meaning to adults' lives. The child's presence may even compete with the marital investment, which, in turn, has a similar function of identity support. Although the couple is considered an important component of the family, children are increasingly holding a central position. In addition, there has been increasing individual freedom to form a family (Borges, Magalhães, \& Féres-Carneiro, 2014). The fact that children can be founders of the family configuration gives them increasing powers. This type of family tends to provide flat, non-hierarchical structures, where cohesion is based on reciprocity.

Lazartigues (2007) emphasized the existence of a mixed culture, in which certain values predominate inside the house and other values predominate outside the house. Because they are very familiar with hedonism in their private life, when they become parents, youths will have a parental practice strongly marked by the influence of the media. This practice is not opposed to the values acquired in the family, at school, and in social groups. According to this author, the consequences of hedonism in children are reduced ability to wait for something they expect to happen, difficulty in establishing relationships with other people, and reduced tolerance to frustration.

Within this mixed culture, at home, there are egalitarian positions, the bonds are symmetrical, and conflict resolution, which resists to consensual approaches, occurs in a relationship of forces. Based on these considerations, Lazartigues (2007) noted that there is an increase of aggressiveness, which is a natural resource when there is conflict; increased dependence of the child in relation to specific family practices; decrease in the vertical transmission of knowledge, which is made invalid by the symmetry of roles; and an early de-idealization of parental figures.

The contemporary family is relational and structured on the mutual recognition of people who live together (Singly, 2007; Singly \& Macher, 2015). In addition, parental authority is challenged, and the child is promoted to a new position inside this dynamic system. Therefore, it is possible to consider that there is a "child authority". To that extent, "new parents" appear as symbols of the new educational frameworks.

Thus, "new children" have some characteristics: absence of a sense of guilt or a faulty sense of guilt in they (their) psychic systems; impulsiveness and intolerance to frustration, which cause numerous difficulties in social relations; and a growing dependence on the environment, although parents and adults that surround them consider them more autonomous. Conversely, when this "new children" become adults, they will have dependent personalities, showing a depressive dimension characterized by a lack of interest in other people (Racamier, 1995).

It is the mission of the family to help with the process of generational transmission, engaging in the articulation of intersubjective spaces (Kaës, 2005). The development of autonomy presupposes a work of development of family dependency bonds. Kaës (2011) pointed out that the prefix "inter" indicates that the distances between two or more individuals make the emergence of the "self" possible. According to this author, it is not possible to exist outside intersubjectivity. This statement is based on the idea that it is necessary to use two logical systems: the logic of processes and internal formations together with the logic of correlations of subjectivities based on conjunction and disjunction. One does not exist without the other and they do not exist without the set that keeps them together.

The notions proposed by Kaës (2011) are in line with Winnicott’s idea (1965) that individuals only exists in their relationship with others, when he discusses the transition from parental care (or maternal care) to individual social life in the route toward relative maturity. Winnicott pointed out that the family serves as a reference for social life. In the unconscious fantasy of the child, every demand refers to the father or mother. The child will gradually demand less and less from parents, being able to enjoy it; however, the unconscious always retains the path back to the parents.

Thus, there are two trends toward relative maturity. One of these trends consists in moving away from the mother, the father, and the family, achieving more and more freedom of action after each step. The other trend occurs in the opposite direction, when the individual tries to preserve or regain the mother and the father. There is a game between these two trends, an interchange that allows the coming and going. Thus, because absolute independence is never achieved, the state of relative dependence that exists in mature family relationships and human relationships in general promotes emotional exchanges, social exchanges, and mutual cooperation (Winnicott, 1965; 1979). Based on the theoretical foundations previously described, this study aims to discuss the process of construction of autonomy in parent-child practices, trying to understand the roles of parents and 
children in this process.

\section{Method}

We used a qualitative method focused on a semi-structured interview including relevant issues related to the exercise of parenting in multiple contemporary family arrangements. We conducted 132 interviews with members of different heterosexual and homosexual family arrangements. The participants were members of middle-class families living in the city of Rio de Janeiro. Forty-one individuals were members of married families (35 heterosexual- and 6 homosexual-parent families), 30 were from separated families ( 25 heterosexual- and 5 homosexual-parent families), 42 were members of remarried families (37 heterosexual- and 5 homosexual-parent families), and 19 were from single-parent families (17 heterosexual- and 2 homosexual-parent families). Family members were divided as follows: 41 mothers, 41 fathers, 26 children aged 7 - 12, and 24 children aged 13 - 18.

Perceptions and narratives of the participants form the database of the present study. The interviews were analyzed using the content analysis method. Data were submitted to analysis method of content in its categorial aspects, in order to investigate, from the discursive material, the meanings attributed by respondents to the phenomena (Bardin, 2011). Through categorial technique, themes were highlighted, arranged by the similarity between the elements contained in the collected material. To achieve this, a "floating reading" was utilized, grouping significant data, identifying them and relating them to highlight the analysis categories. The narratives of respondents in relation to the construction of autonomy provided the following categories: parenting exercise and gender; flexibility; emotional democracy; transgressions and rupture of limits; anxiety of parents towards their children's autonomy process.

For the purpose of presentation of results, the different family arrangements were named as follows: Fam (family), Mar (married), Sep (separated), Rem (remarried), Sing (single parent), Hete (heterosexual parents), and Homo (homosexual parents). Fathers were called F, mothers were called M, sons were called So, and daughters were $\mathrm{Da}$. These categories were ordered within each family arrangement followed by the age of each participant.

Our project was approved by the Research Ethics Committee at the Pontifícia Universidade Católica do Rio de Janeiro. All adult participants signed the Informed Consent form, thus allowing the use of data in teaching, research, and publication. The participating children and adolescents agreed to participate in the study, and their consent form was signed by their parents or guardians.

\section{Results and Discussion}

\subsection{Exercise of Parenting and Gender}

Considering the exercise of parenting in heterosexual and homosexual married, separated, remarried, and single parent families, we found that most parents were confused and ambivalent regarding parental roles, especially in relation to the perception of gender representations. Respondents seemed to promote a contradictory environment, where hesitation, uncertainty, and lack of confidence appear in the definition of parenting.

Let's say that this is a very traditional home (...) Traditional in the bad sense of the word. I feel as if the household chores were my responsibility. They do some chores, but out of consideration for me, you know? Not because these chores are everyone's responsibility. Then I try to insist a little or I throw a fit when I'm overloaded (...) It's quite a sexist story. (FamRemHete, M5, 40, 5-year-old daughter and 16-year-old son)

Sometimes, when I had to decide something [about the daughters] I thought: if J. [mother] were here, how would she think, what would she do? Of course, you can't do exactly the same, but ... (FamSingHete, F3, 56, 18and 22-year-old daughters)

It's just the two of us, you know, so we are becoming good friends, we chat, go out for lunch, go out for a walk and stuff like that, it's great (...) It's complicated for a single parent, you know, I think that when there is a couple, no matter what kind of couple, one plays good cop and the other bad cop. But I have to play both bad cop and good cop at the same time (FamSingHomo, F1, 42, 7-year-old son).

There is explicit uncertainty regarding the performance of parenting roles, as shown by the statements above. The remarried mother (M5) is resentful because her husband and son do not do many household chores, thus she feels overwhelmed. This is consistent with Jablonski's (2010) findings in a study on gender differences in the family. M5 says her family context is sexist, based on traditional principles, where the man "needs" to be asked to collaborate, which enhances his role as a "supporting actor". This perception is in agreement with the state- 
ments by Zanetti and Gomes (2011). These authors believe that there is a rupture between traditional values and new models, which have not been fully implemented within the family so far.

Conversely, the speeches of F3 and F1 - both of them belonging to heterosexual or homosexual single-parent families-focused on the difficulty in performing their parenting roles without a partner. In the heterosexual case, there is lack of references, because single-parent families usually consist of a female parent. Regarding the homosexual family, there is similarity with the descriptions of female single-parent families because, as stated by Grzybowski and Wagner (2010), women who are heads of the household lack support and feel emotionally overloaded.

The diversity in parenting practices related to gender differences are perceived by some children.

My father says "ask your mother", then I ask him: "but do you allow me to go?" and he says "No, but if your mother allows you to go, you can go". If my mother allows me, then I tell him that she allowed me, and he agrees. (...) She does not accept that, but my dad accepts. My mom rarely agrees with my dad when he allows me to go out. (FamMarHete, Da1, 7)

In this context of indecision, family members try to broaden the horizons of their visions of autonomy, taking advantage of the controversial environment. Parents and children seem to identify the critical points of their relationships, the moments of hesitation, and they use these weak points to prepare further attacks with the purpose of broadening their range of personal gain. This perception is aligned with the statements by Henriques, Féres-Carneiro and Ramos (2011), highlighting the game of going away and returning in the relationship, a series of experiments aimed at achieving more freedom of action.

\subsection{Flexibility}

Some of the respondents mentioned they lived in a family environment that was more flexible in terms of family rules. There is an association between a flexible environment and the possibility of family members to question the rules and reformulate them, thus promoting mutual agreements and the acquisition of autonomy.

No, her school uniform, no [she does not choose it], but when we go out, she chooses what to wear, then if I think that's not ok, I tell her: No, this is too warm, or it's too cold outside, put on the blouse, but I let her to choose, she chooses her socks (FamMarHomo, M2, 46, 4-year-old daughter)

Well, there is still some discussion before going out at night because I'm still very young and my mother is afraid of taxi drivers and stuff. But, for example, if I go with more people, it's ok. (FamRemHete, Da9, 15)

These reports show that there is flexibility in the relational environment, with the possibility of gaining more freedom. This is in agreement with Ramos (2006), who stated that interindividual negotiations within the family occur to favor each member's interests.

However, parents have difficulty to change the patterns of behavior that do not include the participation of children in household chores. Next, there are reports of two mothers explaining these statements.

I'm their "maid”, it's true, I wash, I iron, I cook (...) But he doesn't wash a dish, doesn't wash a glass, he leaves ten glasses in the sink, you know. I teach him, I tell him, but I can't ... (FamSingHete, M2, 52, 11year-old son)

It's too many dishes, too many. Then I just do it righ away, I wash everything... Then everyone eats and goes to their rooms. It's difficult. I could not handle this well, no. Because I'm not very authoritarian. I felt sorry for them, then I ended up doing it. (FamSepHomo, M2, 42, 18-year-old daughter)

These reports show how the lack of flexibility to implement the necessary changes-including discussions and formulation of new living arrangements-paralyzes family members, producing feelings of weakness and lack of power. This finding is similar to Singly's (2007) definition of challenge of parental authority in contemporary families, where children and adolescents may be promoted to a new position in family dynamics.

These reports lead to a discussion about the "new children", who seem to have "child authority" and require the construction of "new parents". These parents appear as symbols of new contemporary educational frameworks, as stressed by Lazartigues (2007). Despite the "new children" are considered to have greater autonomy according to the viewpoint of parents and adults who know them, as shown by Racamier (1995) and Ponciano and Féres-Carneiro (2014), this change does not happen without fear and hesitation, which can be detected in children's reports.

I think (it's dangerous). I would feel (fear). It depends (with friends), with a large group, very large, very large, like ten people, I think my mother would allow me, but if I go with two other people, I don't like and I'm 
not allowed to (FamMarHete, So2, 9).

Oh, because... They will not allow me if I tell them, of course, but if I don't tell them, if I'm outside the condo, I'm not safe. I'm with my friends, who are not so... They're not... I can... Sometimes they tease me, they tell me to go, but I wouldn't go. Then, if we cross the street, we don't know... We can get driven over. We are totally unsafe. If someone wants to hurt us, we are quite defenseless (FamSepHete, Da03, 11).

The children's experiences shown in the reports above reveal experiences marked by lack of safety and helplessness regarding the dangerous situations they have to face in the external world. These reports also show that "new parents" have educational projects based on fear of violence, which characterizes contemporary life.

\subsection{Emotional Democracy}

In a relationship between parents and children, where authority is performed in an explicit or implicit manner, it is assumed that individuals are able to express their ideas at the same level of equality. Some parents provide examples of this statement:

He makes a decision and let us know. It is important to let children practice that, not because it is separated from us, but that's it. What do you want? We usually make decisions for our children, and then later we complain that they do not know how to make decisions. (FamRemHete, F8, 42, 13-year-old son)

But then the decisions are made with them. So this is a way to get them to take responsibility for the decisions (...), I think that autonomy is something that has to be achieved, the same goes for freedom, you know, you allow them to have more freedom as they show they can take more responsibility. (FamMarHete, M1, 44, 16-yearold daughter and 13-year-old son)

These reports confirm the statements made by Giddens (1992) regarding the fact that, in an egalitarian environment, arguments are expressed in a democratic manner, where everyone can express themselves. On the other hand, the democratic family speech may be confronted with stricter social behaviors coming from the external world according to Caillé (2003), especially when associated with contemporary conditions of violence, which generate fear and unsafety.

Yeah, he has less autonomy than I had when I was his age. But I think that this is something that happened to everyone, right? When I was 9, I used to take the bus by myself, at least in my neighborhood. When I was 11, I used to go to relatives' homes in different distant neighborhoods. And he does not leave the building alone. He can go down to the playground alone, but the youngest one doesn't do that. (FamRemHomo, M1, 46, 10-year-old son and 5-year-old daughter)

But it's a restricted freedom, you know the deal, right? You can't raise a child in a bubble. He may tell you that he's going to school and skip class and ... screw it up. Then you have to tell him: "Look, you can go, you can go out with your classmates, but I want to know where are, once in a while I'll call you. I'm not tracking you down, but we live in a dangerous world”. (FamRemHete, F1, 54, 25-year-old adopted daughter, 25- and 13-year-old daughters, and 23-year-old son)

Based on these interviews, it is clear that parents are confused and hesitant both in relation to the outside world and its violent context and to their behavior regarding their children. There is lack of continuity in the speech of those who advocate emotional democracy. This leads parents to constantly defend their positions against the liberation movements.

\subsection{Transgression and Rupture of Limits}

The development of autonomy requires development of family dependency bonds (Kaës, 2005). Autonomy is seen as an interindividual process embodied by all members of the family in the current parenting practice. It is worth mentioning that we cannot ignore the knowledge, the expertise these individuals have about their own common life experiences, which are based on the details of accumulated knowledge. Such knowledge is made up of small invisible truths. It may be possible that these individuals constantly try to find ways to move forward within the same environment.

I'm trying to do it this way, me and her [daughter], because I know that she is easy going, I have to know exactly the right time to talk or not, or even let her do things and to know the right time to push her and let her do things. (FamRemHete, F5, 40, 9-year-old son and 3-year-old daughter)

I try to stimulate her to do small chores, when she has to get cup, it is not a glass, it's plastic cup, and he knows that he can get it, so he goes there and picks the cup up. When it comes to homework, I let her alone and 
only help when she asks me to. (FamRemHete, M9, 36, 10- and 4-year-old daughters)

Regarding parental practice, Henriques, Féres-Carneiro and Ramos (2011) stressed that there is an interplay, which resembles what Eiguer (2008) defined as the practice of intersubjectivity, where individuals practice reciprocity and influence one another at different levels. During this interplay, individuals show their capacity to reinvent themselves, which is triggered by movements that express the need not to comply with what is established and to challenge the relationship agreements. This situation appears in a subtle way in children's reports.

(...) many of my friends go from school to the mall by themselves. There are many mothers who allow them to go, and I told my mom: "Oh, mom, I think you will not allow me, but I also would not allow, but can I go to the mall with my friends?". Then she said: "No way"; then I said: "I totally understand, you know, because it is very dangerous, it is... I can be driven over, there may be a bad person who may take me, something like that". Because we are just children, there is not an adult around (FamMarHete, Da02, 10)

My mother (sets the rules). My father also, but my mother said... They sat down and talked... [...] It's... Sleep late, watch TV in the evening, she doesn't allow me to do that, but sometimes I watch a little. (FamRemHete, Da2, 9)

All these experiences lived by children and their parents is determined in intersubjective relationship. The journey to become a father, a mother, a child consists of the recognition and articulation of these psychic spaces, according to Winnicott (1965). During these games, there is breach of the limits and a possibility of transgression of the rules of coexistence. This is aligned with what Henriques, Féres-Carneiro and Ramos (2011) stated about the "wisdom" of family members when they find a critical point in the relational field. After this critical point is detected, they make suggestions for changes.

I had [a curfew to get home]. Nowadays, when there are friends' birthday parties, I often go back ... Well... I say I'll go back at a specific time, and I ... Well... Then I call and I say that I'll be late. There is no longer a curfew to go back. (FamSepHete, Da6, 14)

Among the adolescents we interviewed, we noticed the same movement. In the relational field, they try to reach a limit, to surpass it, and thus gain more freedom of action. When they breach this limit, their achievement becomes a new threshold. Thus, an unlimited movement, a set of constant reconstruction is built in the relational system.

Based on most interviews, it is clear that children and parents often seem to be waiting for the results of subtle advances toward the challenge of a limit. These advances are related to both children and their parents: some of them transgress and the other ones covertly allow the transgression. Therefore, individuals establish a tacit agreement based on personal initiatives and common feelings. The acquisition of autonomy by children promotes the autonomy of parents, thus there is a process of differentiation between them.

\subsection{Anxiety of Parents towards Their Children's Autonomy Process}

We noticed an attempt to achieve more freedom of action, and this is associated with both parents and children. The acquisition of autonomy is an interactive process, where everyone is involved and moves from a state of absolute dependence at birth to the relative autonomy of adulthood (Winnicott, 1965). However, this journey does not seem to happen without hesitation, lack of confidence, and anxieties. Parents express these feelings in the reports below.

It was very uncomfortable when I began to realize that he could make his own decisions and he began to enter a stage in which his decisions (...) were not based only on what will please mom. That's what a child does, right? You tell M. (daughter): M., if you do this mom will be very upset. It's over, right? The child does not want to do anything to make her mother upset. But teenagers occasionally will do. They'll do. And it's very unpleasant, I tell you. (FamRemHete, M5, 40, 16-year-old son and 5-year-old daughter).

So, for me, this is a natural thing... S. also thinks it is. But there is a... When we think of the future, it feels like a pinch in my heart... Because, well, autonomy, at some point, will lead to a separation that will have to happen at some point. But, then, if we are able to postpone it, it's good. But we deal well with this, because they [children] have to become independent in a natural manner. (FamMarHete, M1, 44, 16-year-old daughter and 13-year-old son)

The feelings exposed by M5 and M1 are in agreement with the ideas of Winnicott (1979) related to the autonomy process that begins very early, since the state of primary maternal preoccupation until the mother discontinues her adaptation to the child and fails. This process allows the baby's disillusion experience: the baby 
feels disappointed and awakens from his illusion. It is believed that, at certain moments of a child-parent relationship, the dimension of illusion-disillusion is updated, causing mixed feelings, such as those mentioned by mothers above. Such feelings may be related to a psychological preparation for the loss and mourning occurred at the end of period of fusion.

Thus, this grief is a healthy part of a process of the parent-child relationship during the transition between illusion and disillusion according to this author. In this process, there is both the baby's perception that he is not the center of the world and the mother's perception that she can worry about herself and move on. Thus, the feelings related to the separation of parents and their children may be ambivalent, based on the possible detection of the gains and losses related to everyone's growth. This experience takes place within a logic of reciprocity (Eiguer, 2008; Henriques, Féres-Carneiro, \& Ramos, 2011; Ramos, 2006), stresses the importance of the vividly interplay in parental practices, and underlines how this experience boosts the journey of acquisition of autonomy.

\section{Final Considerations}

According to what was observed in the present study, the construction of autonomy is a process experienced within the relationship between parents and their children. The practices developed in the construction of this process consist of a network of affections that promotes increasing acquisition of autonomy in all family structures we investigated.

We found that there is an interplay, an intersubjective practice, in which there is reciprocity between the individuals, who influence one another at different levels. There is a capacity of reinventing themselves, which is triggered by movements of non-conformity in relation to what has been established, making it possible to discuss and try to renegotiate the relationship agreements.

Children and parents often seemed to be waiting for the developments of their advances in terms of challenging the limits. These experiences relate both to children and parents: the first ones transgress and the other ones covertly allow the transgression. Thus, based on common feelings, we may say that the acquisition of autonomy of children promotes the autonomy of parents, which contributes to the implementation of a process of differentiation between parents and children.

Therefore, we concluded that the construction of autonomy is an interindividual process involving all family members. This process includes a corpus of experiences of everyday parenting practices. The experience of this process, however, is characterized by fears, worries, hesitations, and uncertainties, both for parents and children. These feelings may reveal the dimensions of lack of assurance and helplessness when there is need to face the world, especially for children and adolescents. Conversely, the "new parents" of these "new children" and "new adolescents" say that they have educational projects based on their fears of violence, which characterizes the present moment, and they feel confused about their children's growth and autonomy.

\section{References}

Barbosa, P. V., \& Wagner, A. (2013). Autonomy in Adolescence: Reviewing Concepts, Models and Variables. Estudos de Psicologia (Natal), 18, 649-658. http://dx.doi.org/10.1590/S1413-294X2013000400013

Bardin, L. (2011). Análise de conteúdo. São Paulo: Edições 70.

Bauman, Z. (2003). Amor líquido: Sobre a fragilidade dos laços humanos. Rio de Janeiro: Jorge Zahar.

Borges, C. C., Magalhães, A. S., \& Féres-Carneiro, T. (2014). Liberdade e desejo de constituir família: percepções de jovens adultos. Arquivos Brasileiros de Psicologia, 66, 89-103.

Caillé, P. (2003). Être parent aujourd'hui: Performance d’un role ou vécu d' un état. Dilemmes et contradiction de la position parentale contemporaine. Neuropsychiatrie de l' enfance et de l' adolescence, 51, 137-144. http://dx.doi.org/10.1016/S0222-9617(03)00029-1

Eiguer, A. (1985). Um divã para a família: Do modelo grupal à terapia familiar psicanalítica. Porto Alegre: Artes Médicas.

Eiguer, A. (2008). Jamais moi sans toi. Paris: Dunod

Féres-Carneiro, T., \& Magalhães, A. S. (2014). Transformations de la parentalité: La clinique auprès de familles séparées et de familles reconstituées. Subjetividad y Procesos Cognitivos, 18, 104-121.

Féres-Carneiro, T., Ziviani, C., Magalhães, A. S., \& Ponciano, E. L. T. (2013). Ser pai (mãe), ser filho (a): A resolução de conflitos em famílias contemporâneas casadas. In T. Féres-Carneiro (Ed.), Casal e Família, transmissão, conflito e 
violência (pp. 73-98). São Paulo: Casa do Psicólogo.

Gallagher, I. M., Féres-Carneiro, T., \& Henriques, C. R. (2013). Planos para o futuro: Percepções de filhos adultos coabitantes com os pais. Revista SPAGESP [online], 14, 4-18.

Giddens, A. (1991). As consequências da modernidade (R. Fiker, Trad.). São Paulo: Unesp.

Giddens, A. (1992). A transformação da intimidade (M. Lopes, Trad.). São Paulo: Unesp.

Giddens, A. (2007). O mundo em descontrole (M. L. X. Borges, Trad.). Rio de Janeiro: Record.

Grzybowski, L. S., \& Wagner, A. (2010). O envolvimento parental após a separação. Psicologia: Reflexão e Crítica (UFRGS. Impresso), 23, 289-298.

Henriques, C. R., Féres-Carneiro, T., \& Ramos, E. (2011). Ajustes entre pais e filhos adultos coabitantes: Limite e transgressão. Psicologia em Estudo Maringá, 16, 531-539. http://dx.doi.org/10.1590/S1413-73722011000400004

Houzel, D. (2007). As implicações da parentalidade. In M. C. P. Silva, \& L. Solis-Ponton (Eds.), Ser pai, ser mãe. Parentalidade: um desafio para o terceiro milênio (pp. 35-42). São Paulo: Casa do Psicólogo.

Jablonski, B. (2010). A divisão de tarefas domésticas entre homens e mulheres no cotidiano do casamento. Psicologia, Ciência e Profissão, 30, 262-275. http://dx.doi.org/10.1590/S1414-98932010000200004

Kaës, R. (2005). Os espaços psíquicos comuns e partilhados. São Paulo: Casa do Psicólogo.

Kaës, R. (2011). Um singular plural. São Paulo: Loyola.

Lazartigues, A. (2007). Nouvelles Familles, Nouveaux Enfants, Nouvelles Pathologies. Neuropsychiatrie de l' enfance et de l' adolescence, 55, 304-320. http://dx.doi.org/10.1016/j.neurenf.2007.07.005

Magalhães, A. S., \& Féres-Carneiro, T. (2011). Em busca de uma conjugalidade perdida: quando a parentalidade prevalece. In T. Féres-Carneiro (Ed.), Casal e família: conjugalidade, parentalidade e psicoterapia (pp. 161-172). São Paulo: Casa do Psicólogo.

Ponciano, E. L. T., \& Féres-carneiro, T. (2014). Relação pais-filhos na transição para a vida adulta, autonomia e relativização da hierarquia. Psicologia Reflexão e Crítica, 27, 388-397. http://dx.doi.org/10.1590/1678-7153.201427220

Racamier, P. C. (1995). L'Inceste et l'incestuel. Paris: Apsygee.

Ramos, E. (2006). As negociações no espaço doméstico: Construir a "boa distância” entre pais e jovens adultos “coabitantes”. In M. L. Barros (Ed.), Família e Gerações (pp. 39-63). Rio de Janeiro: FGV.

Reichert, C. B., \& Wagner, A. (2007). Considerações sobre a autonomia na contemporaneidade. Estudos e Pesquisas em Psicologia, 7, 405-418.

Salem, T. (2007). O casal grávido, disposições e dilemas da parceria igualitária. Rio de Janeiro: FGV.

Sant'Ana, R. B. (2009). Autonomia do sujeito: as contribuições teóricas de G. H. Mead. Psicologia, Teoria e Pesquisa, 25, 467-477. http://dx.doi.org/10.1590/S0102-37722009000400002

Singly, F. (2007). Sociologie de la famille contemporaine (2nd ed.). Paris: Nathan.

Singly, F., \& Macher, G. (2015). Avec Guillaume Macher: “Pourquoi la famille est-elle redevenue aimable?”. Sciences Humaines, 266, 42-45.

Wagner, A., \& Grzybowski, L. S. (2003). Uma andorinha sozinha não faz verão? A mulher divorciada e a monoparentalidade familiar. Psicologia Clínica, 15, 13-30.

Winnicott, D. W. (1965). A Família e o Desenvolvimento Individual (M. B. Cipolla, Trad.). São Paulo: Martins Fontes.

Winnicott, D. W. (1979). O ambiente e os processos de maturação (I. C. S. Ortiz Trad.). Porto Alegre: Artmed.

Zanetti, S. A., \& Gomes, I. C. (2011). A “fragilização das funções parentais” na família contemporânea: Determinantes e consequências. Temas em Psicologia, 19, 491-502. 


\section{Submit or recommend next manuscript to SCIRP and we will provide best service for you:}

Accepting pre-submission inquiries through Email, Facebook, LinkedIn, Twitter, etc.

A wide selection of journals (inclusive of 9 subjects, more than 200 journals)

Providing 24-hour high-quality service

User-friendly online submission system

Fair and swift peer-review system

Efficient typesetting and proofreading procedure

Display of the result of downloads and visits, as well as the number of cited articles

Maximum dissemination of your research work

Submit your manuscript at: http://papersubmission.scirp.org/ 